
\title{
3 Research S Suare \\ High Temperature-induced Spindle Destabilization Results in Aborted Pollen Production in Populus
}

\author{
Zhiqun Li \\ Beijing Forestry University \\ Yifan Zhao \\ Beijing Forestry University \\ Xuetong Cheng \\ Beijing Forestry University \\ Bo Kong \\ Beijing Forestry University \\ Yaru Sang \\ Beijing Forestry University \\ Qing Zhou \\ Beijing Forestry University \\ Jian Wu \\ Beijing Forestry University \\ Pingdong Zhang ( $\square$ zhangpd@bjfu.edu.cn ) \\ Beijing Forestry University
}

\section{Research Article}

Keywords: high temperature, aborted pollen, spindle, microtubular cytoskeleton, tapetum, Populus canescens

Posted Date: October 12th, 2021

DOl: https://doi.org/10.21203/rs.3.rs-940050/v1

License: (c) (1) This work is licensed under a Creative Commons Attribution 4.0 International License.

Read Full License 


\section{Abstract}

High temperature can induce the production of $2 \mathrm{n}$ gametes and aborted pollen during microsporogenesis in Populus canescens. However, the mechanism by which high temperature induces pollen abortion remains unknown. Here, pollen abortion was induced by exposing male flower buds of $P$. canescens to 38 and $41{ }^{\circ} \mathrm{C}$; pollen morphology, meiotic abnormalities, defects of the meiotic microtubular cytoskeleton, and tapetum development were characterized, and expression analysis of the Actin gene was conducted. We found that the dominant meiotic stage, temperature, and duration of treatment significantly affected the percentage of high temperature-induced aborted pollen. Damaged spindle microtubules and depolymerized microtubular cytoskeletons were observed, which resulted in many lagging chromosomes at anaphase $\nabla$ and $\otimes$, as well as aneuploid male gametes and micronuclei, generating aborted pollen grains. Tapetum disintegration was also delayed. However, the anther dehisced normally, and some viable pollen grains were released, suggesting that the delayed degradation of the tapetum was not responsible for pollen abortion. A significant reduction in PtActin gene expression was detected in treated cells, indicating that spindle actin was disrupted. The spindle actin appeared to protect cells against chromosome segregation errors during meiosis.

\section{Introduction}

In Populus, high temperature is often used as a physical mutagenic agent to induce $2 \mathrm{n}$ gametes for its procedural advantages and because it allows for the uniformity of treatments ${ }^{1-3}$. Many studies have examined the induction of $2 \mathrm{n}$ gametes by high temperature. Both macrosporogenesis and the development of the embryo sac have been shown to be appropriate phases for inducing $2 \mathrm{n}$ female gametes ${ }^{4,5}$. According to previous studies, $2 n$ female gametes can be induced via high temperature exposure during macrosporogenesis in Populus peeudo-simonii kitag. $\times$ Populus nigar 'Zheyin3\#' and Populus adenopoda Maxim, and several triploids have been created. In addition, hybrid triploids can be obtained through the induction of $2 \mathrm{n}$ eggs by high temperature exposure during the development of the embryo sac in Populus tomentosa Carr. and Polpulus alba $\times$ Populus glandulosa ${ }^{6,7}$. High temperature can also be used to induce $2 \mathrm{n}$ pollen. Kang et al. ${ }^{3,8}$ reported that the highest frequency of induced $2 \mathrm{n}$ pollen via high temperature exposure in $P$. tomentosa $\times$ P. bolleena was $88 \%$. Zhang et al. ${ }^{9}$ showed that the maximum frequency of $2 \mathrm{n}$ pollen that could be induced by high temperature exposure in $P$. alba $\mathrm{L}$. was $39.6 \%$.Tian et al. ${ }^{10}$ demonstrated that high temperature exposure did not affect $2 \mathrm{n}$ pollen viability in Populus canescens (Ait.) Smith, as aborted pollen was commonly observed. However, the mechanism by which aborted pollen is produced by high temperature remains unknown.

Abortion is a common reproductive phenomenon that is closely related to the amount of pollen, pollen viability, fertilization, and growth ${ }^{11}$. Previous studies have identified the following cytological factors as causes of abortion: (i) meiosis, (ii) tapetum development and disintegration, and (iii) cytoskeleton formation and disintegration ${ }^{12-14}$. First, meiosis is particularly susceptible to environmental changes. Many cytological events including cytomixis and abnormal chromosome behaviors occur during meiosis. 
Cytomixis events involving the exchange of chromosomes between meiocytes could contribute to the formation of unbalanced tetrads and polyads, which partly explains pollen abortion ${ }^{15}$. In addition, abnormal chromosome behaviors contribute to aborted pollen. Second, abortion is generally associated with tapetum development and disintegration. On the one hand, tapetum cells might secrete some components such as callose and sporopollenin precursors, which contribute to the dissolution of callose and the formation of exine, respectively ${ }^{16}$. The decrease in callose and sporopollenin might inhibit the development of microspores, leading to pollen abortion ${ }^{17}$. On the other hand, the abnormal enlargement and disintegration of the tapetum can result in a lack of nutrition for microspores and thus lead to abortion ${ }^{13}$. Finally, the cytoskeleton is responsible for mediating dynamic changes during meiosis and thus is closely associated with abortion. For example, aberrant cytoskeletal dynamics and an abnormal distribution of the cytoskeleton can ultimately lead to pollen abortion ${ }^{14}$.

After flower buds are treated with high temperature in higher plants, macrospores or eggs form and mature in the ovule, which can only be observed through paraffin sectioning. Consequently, determining the effects of high temperature exposure on the fertility of female gametes is difficult. However, evaluating the effects of high temperature exposure on the fertility of pollen grains after they are released from anthers is less of a challenge by comparison. The objective of this study was to characterize the mechanism by which aborted pollen forms via high temperature exposure in $P$. canescens. Pollen abortion was induced by temperatures of 38 and $41^{\circ} \mathrm{C}$; pollen morphology, meiotic abnormalities, defects of the microtubular cytoskeleton during meiosis, and tapetum development were characterized, and expression analysis of PtActin gene was conducted. Our findings provide new insights into the mechanisms of heat stress-induced pollen abortion.

\section{Results}

\section{The effects of high temperature on aborted pollen production, pollen morphology and pollen viability.}

Male buds of $P$. canescens developed slowly and anthers became dry and brown after high temperature treatment. Some buds were dead after they were exposed to high temperatures, which precluded pollen collection.

High temperature-induced pollen was collected from all surviving male buds. A high proportion of aborted pollen was observed in addition to some induced $2 \mathrm{n}$ pollen (Figure 1a). Spontaneously aborted pollen was rarely observed in the control group (Figure 1b). The percentage of aborted pollen in different treatments is shown in Table 2. The average percentage of high temperature-induced aborted pollen varied from 9.45 to $25.11 \%$. GLM-univariate analysis of the percentages of high temperature-induced aborted pollen showed that dominant meiotic stage $(F=5.75, P<0.001)$, temperature $(F=25.71, P<0.001)$, and duration of treatment $(\mathrm{F}=17.82, P<0.001)$ significantly affected the percentages of high temperature-induced aborted pollen. Dominant meiotic stage $\times$ temperature $(F=3.96, P=0.004)$ and 
dominant meiotic stage $\times$ duration $(F=5.48, P<0.001)$ interactions also significantly affected the percentage of high temperature-induced aborted pollen. Temperature $\times$ duration $(F=2.40, P=0.128)$ and dominant meiotic stage $\times$ temperature $\times$ duration $(F=1.21, P=0.319)$ interactions had no significant effect on the percentage of high temperature-induced aborted pollen. LSD multiple comparison tests showed that the differences in induced aborted pollen production were significantly higher at the diplotene stage than at the leptotene, pachytene, diakinesis, and metaphase I stages $(a=0.05)$. The percentage of high temperature-induced aborted pollen was higher at $41^{\circ} \mathrm{C}$ than at $38^{\circ} \mathrm{C}$. The percentage of high temperature-induced aborted pollen was higher for samples that were treated after $6 \mathrm{hr}$ than after $3 \mathrm{hr}$.

Pollen morphology was studied by scanning electron microscopy. The pollen grains within the control group was uniform, spherical, with few corrugations and granular surface (Figure 2a, $d$ and g). There was no aperture on surface. Few aborted pollen grains (arrows) were induced (Figure 2b and c) by $38^{\circ} \mathrm{C}$ high temperature for 3 or $6 \mathrm{hr}$. The morphology (Figure 2e, $\mathrm{f}, \mathrm{h}$ and i) and the ectexine deposition (Figure $2 \mathrm{~d}$ and g) of induced pollen were similar to the control group, suggesting that high temperature had no significant effects on the pollen morphology.

For evaluation of induced pollen viability, Fresh high temperature-induced pollen grains were supplied for germination test on the medium containing $0.7 \%$ agar, $50 \mathrm{mg} / \mathrm{L}$ calcium chloride, $120 \mathrm{mg} / \mathrm{L}$ boric acidm. Some germinated pollen grains were, respectively, observed for the control (Figure 3a), treatment at $38{ }^{\circ} \mathrm{C}$ for $3 \mathrm{hr}$ (Figure 3b) and treatment at $38^{\circ} \mathrm{C}$ for $6 \mathrm{hr}$ (Figure 3c) groups. Pollen germination rates are showed in Figure 3d. After $6 \mathrm{hr}$ of culture, the average gerimation rate in the control group was $26.95 \%$, which was slightly higher than that of induced pollen after treatments at $38{ }^{\circ} \mathrm{C}$ for $3 \mathrm{hr}(21.52 \%)$ and at $38^{\circ} \mathrm{C}$ for $6 \mathrm{hr}(20.29 \%)$, indicating that the frequencies of aborted pollen in the treatment groups were slightly higher than that in the control group. Among the treatments, the average germination rate of induced pollen via $38^{\circ} \mathrm{C}$ treatment for $3 \mathrm{hr}$ slightly higher than that of induced pollen via $38^{\circ} \mathrm{C}$ treatment for 6 hr. However, the GLM-Univariate analysis of germination rates revealed that high temperatures had no significant effect on induced pollen germination rates.

\section{Induced meiotic abnormalities by high temperature.}

In male flower buds that were exposed to $38^{\circ} \mathrm{C}$ for 3 or $6 \mathrm{hr}$ at the diploptene stage, all treated flower branches continued to be hydroponically cultured until pollen was released from the anthers. At the anaphase I, anaphase II, and tetrad stages, five flower buds per treatment were sampled to determine the effect of high temperature on the meiosis of PMCs. In the control group, the PMCs underwent normal meiosis, and a few lagging chromosomes in some PMCs were observed at anaphase I (Figure 4a) or anaphase II (Figure 4b). The number of lagging homologous chromosomes varied from one to eight, and the percentage of PMCs with lagging homologous chromosomes was $22.7 \pm 4.2 \%$ at anaphase I. The number of lagging sister chromosomes varied from one to ten, and the percentage of PMCs with lagging sister chromosomes was $13.3 \pm 5.0 \%$ at anaphase II (Table 2 ). 
In some PMCs exposed to $38^{\circ} \mathrm{C}$, meiosis was abnormal, and a large number of lagging chromosomes were observed at anaphase I or II (Figure $4 \mathrm{~d}, \mathrm{f}, \mathrm{g}$ and $\mathrm{h}$ ). After $3 \mathrm{hr}$ of treatment at $38{ }^{\circ} \mathrm{C}$, the number of lagging homologous chromosomes varied from 1 to 13 , and the percentage of PMCs with lagging homologous chromosomes was $40.7 \pm 3.1 \%$ at anaphase I. The number of lagging sister chromosomes varied from one to 20 , and the percentage of PMCs with lagging sister chromosomes was $33.3 \pm 8.0 \%$ at anaphase II (Table 3). The percentage of PMCs with lagging homologous or sister chromosomes was significantly higher after treatment at $38^{\circ} \mathrm{C}$ for $3 \mathrm{~h}$ compared with the control group. When PMCs were treated at $38^{\circ} \mathrm{C}$ for $6 \mathrm{hr}$, the number of lagging homologous chromosomes varied from one to 28 , and the percentage of PMCs with lagging homologous chromosomes was $55.3 \pm 4.2 \%$ at anaphase I. The number of lagging sister chromosomes varied from one to 23 , and the percentage of PMCs with lagging sister chromosomes was $48.7 \pm 3.1 \%$ at anaphase II (Table 3 ). The percentage of PMCs with lagging homologous or sister chromosomes was slightly higher after treatment at $38{ }^{\circ} \mathrm{C}$ for $6 \mathrm{hr}$ compared with PMCs treated at $38^{\circ} \mathrm{C}$ for $3 \mathrm{hr}$.

After two rounds of cell division, normal cytokinesis occurred in the control group, resulting in tetrad formation (Figure 4c). However, few micronuclei were observed in some of the treated PMCs (Figure $4 \mathrm{f}$ and i), and some polyads formed at the tetrad stage, suggesting that chromosome segregation errors occurred and led to the production of aneuploid gametes.

\section{Delayed tapetum development is not responsible for induced aborted pollen production.}

Defective tapetum development is often associated with the disrupted development of meiocytes and/or pollen and reduced/impaired fertility ${ }^{20}$. We examined the effect of high temperature on tapetum development via sectioning and toluidine blue staining during microspore maturation. At the tetrad stage in the control group, the tapetum was observed in the anther, which surrounded the developing PMCs (Figure 5a). Two days after the tetrad stage, the tapetum degenerated normally by programmed cell death (PCD) (Figure 5b). Four days after the tetrad stage, thinner tapetal layer cells were observed in the anther (Figure 5c). Six days after the tetrad stage, no tapetal layer cells in the anther were observed (Figure 5d). Eight days after the tetrad stage, the anther dehisced, and a large number of pollen grains with good fertility were released (Figure $5 e$ ).

At the tetrad stage in the group exposed to $38^{\circ} \mathrm{C}$ for $3 \mathrm{hr}$, the tapetum was observed in the anther, which surrounded the developing PMCs (Figure 5f). Two days after the tetrad stage, tapetum degenerated gradually by PCD (Figure $5 \mathrm{~g}$ ). Four days after the tetrad stage, thinner tapetal layer cells were observed in the anther (Figure $5 \mathrm{~h}$ ). Six days after the tetrad stage, few tapetal layer cells in the anther were observed (Figure $5 \mathrm{i}$ ), suggesting that the tapetum of the treated anthers degenerated more slowly than the tapetum in the control group. Eight days after the tetrad stage, the anther matured, and more abortive pollen grains were released (Figure 5j). A similar pattern of tapetum degeneration was observed for PMCs exposed to 
$38^{\circ} \mathrm{C}$ for $6 \mathrm{hr}$ (Figure $\left.5 \mathrm{k}-\mathrm{n}\right)$, except that many more abortive pollen grains were released after anthers matured (Figure 50).

\section{Induced spindle destabilization results in aborted pollen production.}

Because the meiotic microtubular cytoskeleton plays an important role in the segregation of homologous and sister chromosomes during meiosis, we examined the integrity and localization of microtubule structures of meiocytes exposed to $38^{\circ} \mathrm{C}$ for 3 or $6 \mathrm{hr}$ using tubulin-a immunocytology. Under control conditions, the microtubular cytoskeleton was distributed regularly in microsporocytes (Figure 6a-h), which allowed for the proper segregation of chromosomes in daughter cells. After PMCs were treated at $38^{\circ} \mathrm{C}$ for $3 \mathrm{hr}$ or $6 \mathrm{hr}$ at the diplotene, all meiotic stages exhibited the same microtubular distribution pattern (Figure 6i-x), similar to unstressed meiocytes (Figure 6a-h). However, the high temperature treatment resulted in some defects in the meiotic microtubular cytoskeleton. For example, the microtubules depolymerized and were not present in the cytoplasm. The extent of the treatment affected the degree of microtubule destabilization, and the plasma membrane even ruptured in some cells.

In the metaphase of the first meiotic division, a single bipolar spindle microtubule depolymerized in cells treated at $38^{\circ} \mathrm{C}$ for $3 \mathrm{hr}$ (Figure $6 \mathrm{j}$ ) and was damaged in cells treated at $38^{\circ} \mathrm{C}$ for $6 \mathrm{hr}$ (Figure $6 \mathrm{r}$ ). The damaged spindle microtubule resulted in the slow movement of chromosomes within the cytoplasm.

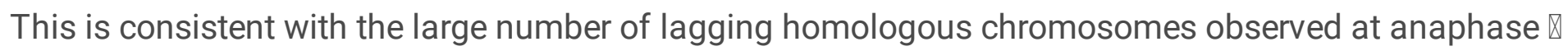

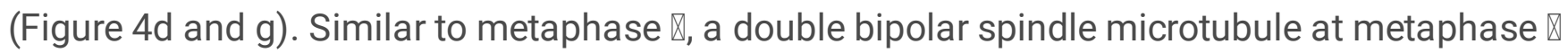
depolymerized in cells treated at $38^{\circ} \mathrm{C}$ for $3 \mathrm{hr}$ (Figure $6 \mathrm{n}$ ) and was damaged in cells treated at $38^{\circ} \mathrm{C}$ for $6 \mathrm{hr}$ (Figure 6v). Subsequently, several lagging sister chromosomes at anaphase $\otimes$ were observed (Figure 4 and $h$ ).

Under control conditions, telophase II male meiocytes typically generate a microtubule network that consists of six tetrahedrally arranged phragmoplast-like structures, which are localized between the four haploid nuclei (Figure $6 \mathrm{~h}$ ). However, telophase II male meiocytes treated at $38^{\circ} \mathrm{C}$ for $3 \mathrm{hr}$ generated a new complex microtubule network that surrounded more than four nuclei instead of the six tetrahedrally arranged phragmoplast-like structure. Microtubule bundles between two nuclei were much thinner in cells treated at $38^{\circ} \mathrm{C}$ for $6 \mathrm{hr}$ than cells treated at $38^{\circ} \mathrm{C}$ for $3 \mathrm{hr}$ and control cells.

\section{The expression of PtActin is down-regulated by high temperature.}

The F-actin cytoskeleton mediates a variety of essential biological functions in eukaryotic cells, as its dynamic properties drive chromosomal movement during cell division. We hypothesized that the expression of PtActin is affected under heat stress conditions. To test this hypothesis, we monitored the 
expression of PtActin in male flower buds derived from the treated groups and control group using qRTPCR. We detected a significant $(p<0.001)$ decrease in the expression of PtActin when the PMCs of $P$. canescens at the diplotene were exposed to $38^{\circ} \mathrm{C}$. The relative expression of PtActin was only $9.2 \pm 0.9 \%$ in PMCs after treatment at $38{ }^{\circ} \mathrm{C}$ for $3 \mathrm{hr}$, which was slightly lower compared with PMCs treated at $38^{\circ} \mathrm{C}$ for $6 \mathrm{hr}(13.7 \pm 1.2 \%)$ (Figure 7$)$, indicating that high temperature significantly affects the transcription of PtActin.

\section{Discussion}

Heat stress $\left(32\right.$ to $\left.40^{\circ} \mathrm{C}\right)$ will decline pollen viability. Many former studies have showed a decrease in the number of produced and released pollen grains ${ }^{21,22}$, a reduction in pollen viability ${ }^{23}$, as well as changes in both the pollen wall structure ${ }^{21,23}$ and female fertility ${ }^{24,25}$. Pollination in flowering plants sometimes were affected by the high temperature. Koti et al. ${ }^{2}$ documented that exposing to high day/night temperatures $\left(38 / 30^{\circ} \mathrm{C}\right)$ affected the pollen tube growth in soybean during flowering. When flowering Brassica napus was treated at $35^{\circ} \mathrm{C}$ for $4 \mathrm{hr}$, a reduction in the pollen germination rate was observed by Young et al. ${ }^{25}$. Cross et al. reported that the process of fertilization in flax was affected by cyclical (daytime high $40^{\circ} \mathrm{C}$ and night-time low $18^{\circ} \mathrm{C}$ ) heat stress 12 days after the initiation of flowering ${ }^{26}$. Subsequent events, such as embryogenesis and seed maturation, were also shown to be potentially sensitive to heat stress, leading to progenies with increased leaf area or delayed bud formation and dehardening ${ }^{27-29}$.

In our study, high temperatures ( 38 and $41^{\circ} \mathrm{C}$ ) were shown to be capable of inducing the production of a large amount of aborted pollen. Suitable high temperature exposure affected the amount of aborted pollen in both a dosage- and meiotic stage-dependent manner. Flower buds had higher amounts of aborted pollen when exposed to higher temperatures. Heat exposure during microsporogenesis has been suggested to lead to pollen abortion in various species such as Phaseolus vulgaris ${ }^{23}$, Capsicum annuum $^{30}$, Oryza sativa ${ }^{31}$, Solanum lycopersicum ${ }^{32,33}$, and wheat ${ }^{34,35}$. However, in $P$. canescens, this response is only observed during a narrow window of development (limited to meiosis), which was consistent with the findings of ${ }^{11}$ in Rosa.

Meiosis is a specialized type of cell division that gives rise to daughter cells with reduced numbers of chromosomes. The reliable segregation of chromosomes is particularly important during meiosis, which is the specialized cell division that results in the formation of eggs and sperm. The egg and the sperm need to have one copy of each chromosome to give rise to a healthy embryo upon fertilization. If normal

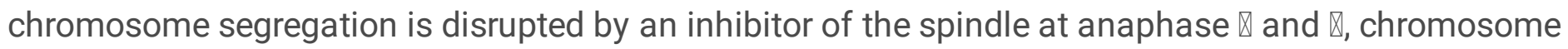
segregation errors during meiotic division lead to the production of aneuploid gametes.

Given rapid changes in global climate, the effects of temperature on plant reproduction have received increased interest ${ }^{36}$. The process of meiosis of PMCs is sensitive to high temperature stress. Therefore, rising global temperatures threaten global crop production ${ }^{37}$. Previous studies have shown that heat 
stress results in numerous meiotic abnormalities, including chromosome stickiness, laggards, micronuclei, and spindle disorientation in the second meiotic division and aberrant cytokinesis, which suggests that meiosis in higher plants is sensitive to heat stress ${ }^{38,39}$.

Here, male flower buds of $P$. canescens at the diplotene stage during the first cell division were exposed to $38^{\circ} \mathrm{C}$ for 3 or $6 \mathrm{hr}$. After high temperature treatment, chromosome segregation was delayed, and several lagging chromosomes were observed at anaphase $\nabla$ and $\otimes$, resulting in the formation of aneuploid gametes and micronuclei. Some polyads were observed at the tetrad stage. Therefore, the aborted development of male meiocytes was observed prior to meiotic cytokinesis. This is consistent with observations of aborted pollen induced by $38^{\circ} \mathrm{C}$ treatment in previous experiments ${ }^{10}$.

- The tapetum that is located at the interface between gametophytic and sporophytic tissues and provides important elements for the development of male gametophyte, such as callase or sporopollenin precursors to help callose dissolution and exine formation, respectively ${ }^{16}$. The process of the tapetum development can, generally, be divided into three stages: tapetum specification, tapetal cells binucleation, and degeneration through $\mathrm{PCD}^{16}$. The fate of sexual cells and anther somatic cells is determined at floral stage 8/anther stage 4 . However, both the tapetum and PMCs form at floral stage 9 and anther stage 5 in Arabidopsis ${ }^{40}$, respectively. Defective tapetum development is often related to the disrupted development of meiocytes and/or pollen and reduced/impaired fertility $20,41,42$. For instance, the formation of the normal microspore cell wall and the fertility level can be affected by a lack of callase or a temporal shift in its activity. Jin et al. documented that a lack of callase production could lead to complete male sterility in Glycine max $^{17}$. Early callose degradation was found to be sufficient for causing male sterility in Nicotiana tabacum ${ }^{43}$.

Many previous studies have shown that heat stress can lead to male sterility in Oryza sativa L., Solanum melongena L., and Solanum lycopersicum Lam ${ }^{44,45}$. For example, in heat-susceptible rice plants, heat stress lasting 4 days or longer during the early phase of anther development caused the premature degradation of tapetum cells and PCD, leading to complete male sterility 46,47 . PCD is crucial for breaking down anther wall cells, such as in the tapetum and middle layer during pollen grain maturation and anther dehiscence ${ }^{48,49}$. After male flower buds of $P$. canescens were treated at $38^{\circ} \mathrm{C}$ for 3 or $6 \mathrm{hr}$, the degradation of the tapetum was delayed. However, the anther dehisced normally, and some viable pollen grains were released, suggesting that the delayed degradation of the tapetum was not responsible for the production of aborted pollen.

During microgenesis, both the movement of homologous or sister chromosomes and postmeiotic cytokinesis are closely related to dynamic changes in the organization of microtubules ${ }^{50,51}$. In diploid Populus species, the misorientation of spindle microtubules and the failure of postmeiotic cytokinesis have been attributed to the formation of unreduced gametes ${ }^{9}$, 39, 52. In Arabidopsis (Arabidopsis thaliana), callose and other cell plate components are deposited at the division planes by a network of microtubule 
(MT) arrays. The production of diploid male gametes in Arabidopsis can be induced by the cold-induced destabilization of postmeiotic radial microtubule arrays ${ }^{53}$.

During cell division, chromosome segregation is considered to be driven by a spindle consisting of microtubules. Firstly, The microtubules capture and align the chromosomes at the spindle center. The chromosomes are, during anaphase, segregated and move to the poles of spindles. The movement of chromosomes is pulled by the shortening of microtubule bundles which are linked to the chromosomes' kinetochores ${ }^{54}$. These kinetochore fibers (K-fibers) combine with a great number of microtubuleassociated motor and nonmotor proteins to align and segregate the chromosomes ${ }^{55}$.

A previous study showed that heat stress induced the depolymerization of the meiotic microtubular cytoskeleton, resulting in the failure of chromosome segregation in Populus. Microtubular cytoskeleton was able to repolymerize in some heat-treated cells after they were placed under normal conditions. However, aberrant cytokinesis occurred because of defects of the new radial microtubule systems, leading to the production of monads, dyads, triads, and polyads ${ }^{56}$. In our study, high temperature induced the depolymerization of meiotic microtubular organization and damaged the spindle microtubules, resulting in homologous chromosome and sister chromosome segregation errors at anaphase I and $\mathbb{\nabla}$. Some chromosomes were retained in the cytoplasm of microsporocytes because of the lack of shortening of the microtubule bundles. Therefore, high temperature-induced spindle destabilization was responsible for aborted pollen production.

Plant actins and the Arabidopsis actin gene family in particular have been extensively studied ${ }^{57-59}$. Factin is a ubiquitous component of the plant cytoskeleton and participates in various important subcellular processes ${ }^{60,61}$. Despite the fact that F-actin is a fundamental component of animal cells, the role of F-actin in plants has not been well characterized ${ }^{62}$. Tissue-specific and developmental expression patterns of actin genes have been studied in several plant species ${ }^{61,63}$.

Actin filaments generate the force required for cytoplasmic streaming in Nitella ${ }^{64}$. Actin appears to function in other motile processes in plant cells, such as the movement of cellular organelles, especially chloroplast aggregation ${ }^{65}$ and rotation ${ }^{65,66}$; it also might mediate membrane movement and chromosome movement during mitosis and meiosis ${ }^{67}$. Although F-actin has been reported in the spindles of various species, it is generally not thought to be involved in chromosome segregation ${ }^{68}$. However, a recent study reported that $\mathrm{F}$-actin played an important role in protecting mammalian eggs against chromosome segregation errors during meiosis ${ }^{69}$. Disrupting spindle F-actin in mouse eggs led to significantly greater numbers of misaligned chromosomes as well as lagging chromosomes during meiosis $\nabla$ and $\otimes$. The speed of chromosome movement was also reduced. In this study, after male flower buds of $P$. canescens were treated at $38^{\circ} \mathrm{C}$ for 3 or $6 \mathrm{hr}$, a dramatic decrease in the relative expression of

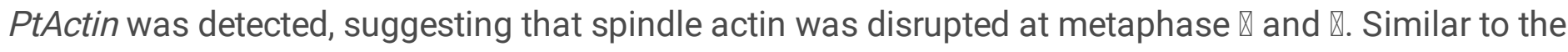
findings of Moessie and in mice ${ }^{69}$, a great number of lagging chromosomes were observed during 
meiosis $\otimes$ and $\bigotimes$. Therefore, the spindle actin appeared to protect PMCs against chromosome segregation errors during meiosis. However, the detailed function of spindle actin in Populus still need further study.

\section{Materials And Methods \\ Plant materials.}

Male floral branches $(2 n=2 x=38)$ of $P$. canescens were collected from a natural population in Aletai, Xinjiang Uygur Autonomous Region, China. All sampled male branches were trimmed and cultured in tap water in a greenhouse $\left(10-20^{\circ} \mathrm{C}\right)$ located in Beijing Forestry University to promote floral development. No nutrients were added to the tap water.

\section{High temperature exposure and detection of aborted pollen.}

High temperature exposure was conducted according to the methods described by Tian et al. ${ }^{10}$ Male flower buds were sampled at the following dominant meiotic stages: leptotence, zytotence, pachytence, diplotence, diakinesis, and metaphase I. The male flower buds were exposed to temperatures of 38 and $41^{\circ} \mathrm{C}$ for 3 and $6 \mathrm{hr}$, respectively. Untreated male flower buds were used as the control group. After each treatment, all treated flower branches continued to be hydroponically cultured until anthers matured. Pollen samples were collected and stored in tubes with allochronic silica gel. To detect aborted pollen, some pollen grains were sampled, spread on a microscopic slide with a needle, and mounted in a drop of aceto-carmine solution (2\%). Pollen grains were stained with acetocarmine solution, and unstained pollen grains were considered aborted pollen.

For scanning electron microscopy analysis, fixed pollen grains were rinsed with ethanol and air-dried. Samples were sputter-coated with gold using a HITACHI E-1010 ion sputter coater and observed under a HITACHIS-3400N microscope, with an accelerating voltage of $5 \mathrm{kV}$.

For evaluation of induced pollen viability, pollen germination test in vitro was conducted according to the methods reported by Zhao et al. ${ }^{18}$ The medium for pollen germination had a pH value of 6.0. Pollen germination was conducted in a climate chamber at $26^{\circ} \mathrm{C} .6 \mathrm{hr}$ after culture, the sampled pollen grains were fixed in Carnoy's fluid for $10 \mathrm{~min}$ after being centrifuged for $5 \mathrm{~min}$ at a speed of 1,000 rpm. The germination rate of each sample was calculated using an eyepiece micrometre. A total of 300-600 pollen grains were assessed per sample. The germination rate was estimated by the number of germinated pollen grains and the total number of sampled pollen grains.

\section{Meiotic analysis of pollen mother cells.}


As previously described by Tian et al. ${ }^{10}$, when all treatments were finished, two to three flower buds were randomly sampled from the control group and the treatment groups every $2 \mathrm{hr}$ and fixed in Carnoy's fluid (ethanol:acetic acid, 3:1) until tetrads appeared. After $24 \mathrm{hr}$, the fixed male buds were transferred to a $70 \%$ ethanol solution and stored in a refrigerator at $4^{\circ} \mathrm{C}$. For meiosis analysis, some anthers were dissected from the fixed buds using forceps and were crushed in a drop of aceto-carmine solution (2\%) onto a microscope slide. Photomicrographs of developing microsporocytes (characterized by different meiotic stages) were placed under a fluorescence microscope (model BX51; Olympus, Japan) with a CCD camera (model DP70; Olympus). A total of 200-300 pollen mother cells (PMCs) were counted per sample.

\section{Tubulin immunolocalization.}

The fresh anthers were randomly sampled from the control group and treatment groups and fixed in $4 \%$ paraformaldehyde (PEM buffer, $\mathrm{pH}$ 6.9) for $60 \mathrm{~min}$. Next, a-tubulin immunolocalization analysis of PMCs during meiosis was performed as described previously ${ }^{19}$. Photomicrographs of developing microsporocytes (characterized by different meiotic stages) were collected with a Leica TCS-SP8 confocal laser scanning microscope.

\section{Observation of tapetum development during microspore maturation.}

when PMCs were at the tetrad stage, two to three flower buds were randomly sampled from the control and treated groups every two days and fixed in Carnoy's fluid. After $24 \mathrm{hr}$, the fixed male buds were transferred to the $70 \%$ ethanol solution and stored in a refrigerator at $4^{\circ} \mathrm{C}$. For observation of tapetum development, some anthers were dissected from the fixed buds using forceps and dehydrated in alcohol and xylene, embedded with paraffin, and sectioned for $8 \mu \mathrm{m}$. The sections were stained with toluidine blue and photographed under an Olympus BX51 microscope.

\section{Expression analysis.}

The expression analysis was conducted as the measures described by Nico et al. ${ }^{70}$. Sequences of primers used for the specific amplification of PtActin and housekeeping gene transcripts along with the corresponding qRT-PCR settings are listed in Table 1 . The $2^{-\triangle \Delta C t}$ method was used to calculate the relative expression levels of candidate transcripts.

\section{Statistical analysis.}

We used a general linear model (GLM) to determine the effect of meiotic stage, temperature, and duration of treatment on the abortion rate of pollen. Data for the abortion rate of induced pollen were transformed 
$(1 / p)$ before analyses of variance to achieve homogeneous variances. All statistical analyses were conducted with SPSS software (SPSS for Windows, Version 13, SPSS, Chicago, IL).

\section{Conclusion}

This study strengthens the effects of high temperatures on the development of PMCs of Populus during meiosis. The dominant meiotic stage, temperature, and duration of treatment significantly affected the percentage of high temperature-induced aborted pollen. Damaged spindle microtubules and depolymerized microtubular cytoskeletons were observed, which resulted in many lagging chromosomes

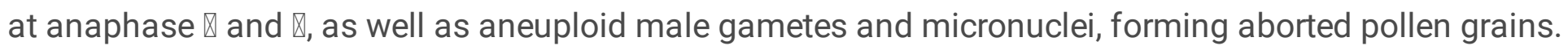
Tapetum disintegration was also delayed. However, the anther dehisced normally, and some viable pollen grains were released, suggesting that the delayed degradation of the tapetum was not responsible for pollen abortion. A significant reduction in PtActin gene expression was detected in treated cells, indicating that spindle actin was disrupted. The spindle actin appeared to protect cells against chromosome segregation errors during meiosis.

\section{Declarations}

\section{Acknowledgements}

We thank Meiqin Liu and Junna Shi for their scanning electron microscopy analysis. We also thank Dr. Christopher A. at University of North Carolina at Chapel Hill for his language editing. This research was financially supported by the National Science Foundation of China (31570646).

\section{Author contributions statement}

P.Z. conceived the research. Z.L., Y.Z., X.C., P.Z., B.K., Y.S., Q.Z., and J.W. performed experiments. Z.L. and P.Z. analyzed the data. Z.L. and P.Z. wrote the manuscript.

\section{Competing interests statement}

The authors have no conflicts of interest to declare.

\section{Data availability statement}

All the data that support the findings of this study are provided in the submission.

\section{Plant availability statement}


Our experimental research and field studies on Populus canescens (either cultivated or wild), including the collection of Populus canescens, are complying with relevant institutional, national, and international guidelines and legislation. We confirm that all methods were carried out in accordance with relevant guidelines in the method section. We also confirm that we have permission to collect the Populus canescens.

\section{References}

1. Randolph, L. F. Some effects of high temperature on polyploidy and other variations in maize. Proc Natl Acad Sci USA. 8, 222-229, DIO:http://dx.doi.org/10.1073/pnas.18.3.222 (1932).

2. Mashkina, O. S., Burdaeva, L. M., Belozerova, M. M. \& Vyunova, L.N. Method of obtaining diploid pollen of woody species. Lesovedenie. 1, 19-25 (1989).

3. Kang, X. Y., Zhu, Z. T. \& Zhang, Z. Y. Suitable period of high temperature treatment for $2 \mathrm{n}$ pollen of Populus tomentosa $\times$ P. bolleana. J Beijing For Univ. 22, 1-4, DIO: http://dx.doi.org/10.13332/j.1000-1522.2000.03.001 (2000a).

4. Lu, M., Zhang, P. D. \& Kang, X.Y. Induction of $2 n$ female gametes in Populus adenopoda maxim by high temperature exposure during female gametophyte development. Breed Sci. 63, 96-103, DIO: http://dx.doi.org/10.1270/jsbbs.63.96 (2013).

5. Wang, J., Li, D. L. \& Kang, X. Y. Induction of unreduced megaspores with high temperature during megasporogenesis in Populus. Ann For Sci. 15, 1-9 (2012).

6. Kang, N., Bai, F. Y., Zhang, P. D. \& Kang, X.Y. Inducing chromosome doubling of embryo sac in Populus tomentosa with high temperature exposure for hybrid triploids. J. Beijing For. Univ. 37,7986, DIO: http://dx.doi.org/10.13332/j.cnki.jbfu.2015.02.021 (2015).

7. Li, Y. J., Tian, M. D. \& Zhang, P. D. Embryo sac chromosome doubling in Populus alba $\times$ P. glandulosa induced by high temperature exposure to produce triploids. Breed Sci. 67, 233-238, DIO: http://dx.doi.org/10.1270/jsbbs.16193 (2017).

8. Kang, X. Y., Zhu, Z. T. \& Zhang, Z.Y. Breeding of triploids by the reciprocal crossing of Populus alba $\times$ P. glandulosa and P. tomentosa $\times$ P. Bolleana. J Beijing For Univ. 22, 811, DIO: http://dx.doi.org/10.13332/j.1000-1522.2000.06.003 (2000b).

9. Zhang, L., Wang, J., Suo, Y. J. \& Kang, X. Y. Pollen chromosome doubling under high temperature in Populus alba. J Nucl Agric Sci. 24, 1158-1165, DIO: http://dx.doi.org/10.1016/S18763804(11)60004-9 (2010).

10. Tian, M. D., Zhang, Y., Liu, Y., Kang, X. Y. \& Zhang, P.D. High temperature exposure did not affect induced 2n pollen viability in Populus. Plant Cell Environ 41, 1383-1393, DIO: http://dx.doi.org/10.1111/pce.13165 (2018).

11. Pécrix, Y., Rallo, G., Folzer. H., Cigna, M., Gudin, S. \& Le, Bris, M. Polyploidization mechanisms: temperature environment can induce diploid gamete formation in Rosa sp. J Exp bot. 62, 3587-3597, DIO: http://dx.doi.org/10.1093/jxb/err052 (2011). 
12. Guan, J. Z., Wang, J. J., Cheng, Z. H., Liu, Y. \& Li, Z. Y. Cytomixis and meiotic abnormalities during microsporogenesis are responsible for male sterility and chromosome variations in Houttuynia Cordata. Genet Mol Res. 11, 121-130, DIO: http://dx.doi.org/10.4238/2012.January.17.2 (2012).

13. Liu, L. W., Huang, H., Gong, Y. Q., Chen, C. S. \& Wang, L. Z. Cytological and ultra-structural study on microsporogenesis of cytoplasmic male sterility in Raphanus sativus. J Integr Plant Biol. 51, 850857, DIO: http://dx.doi.org/10.4238/2012.January.17.2 (2009).

14. Xu, C. G., Liu. Z. T., Zhang. L. P., Zhao, C. P., Yuan, S. H. \& Zhang, F. T. Organizaiton of actin cytoskeleton during meiosis 区in a wheat thermo-sensitive genic male sterile line. Protoplasma. 250, 415-422 DIO: http://dx.doi.org/10.1007/s00709-012-0386-6 (2013).

15. Singhal, V. K. \& Kumar, P. Cytomixis during microsporogenesis in the diploid and tetraploid cytotypes of Withania somnifera (L.) dunal, 1852 (solanaceae). Comp Cytogenet. 2,85-92, DIO: http://dx.doi.org/10.1155/2008/451930 (2008).

16. Scott, R. J., Spielman, M. \& Dickinson, H. G. Stamen structure and function. Plant Cell. 16, 46-60, DIO: http://dx.doi.org/10.1105/tpc.017012 (2004).

17. Jin, W., Horner, H. T. \& Palmer, R. G. Genetics and cytology of a new genic male-sterile soybean [Glycine max (L.) Merr.]. Sex Plant Reprod. 10, 13-21, DIO: http://dx.doi.org/10.1007/s004970050062 (1997).

18. Zhao, C. G., Tian, M. D., Li, Y. J. \& Zhang, P. D. Slow-growing pollen-tube of colchicine-induced 2n pollen responsible for low triploid production rate in Populus. Euphytica. 213, 94, DIO: http://dx.doi.org/10.1007/s10681-017-1881-9 (2017).

19. Zhang, P. D. \& Kang, X. Y. Occurrence and cytological mechanism of numerically unreduced pollen in diploid Populus euphratica. Silvae Genet. 62, 285-291, DIO: http://dx.doi.org/10.1515/sg-201-004 (2013).

20. Chen, Z. S., Liu, X. F., Wang, D. H., Chen, R., Zhang, X. L., Xu, Z. H. \& Bai, S. N.Transcription factor OsTGA10 is a target of the MADS protein OsMADS8 and is required for tapetum development. Plant Physiol. 176, 819-835, DIO: http://dx.doi.org/10.1104/pp.17.01419 (2018).

21. Koti, S., Reddy, K. R., Reddy, V. R., Kakani, V. G. \& Zhao, D. L. Interactive effects of carbon dioxide, temperature, and ultraviolet-B radiation on soybean (Glycine max L.) flower and pollen morphology, pollen production, germination, and tube lengths. J Exp bot. 56, 725-736, DIO: http://dx.doi.org/10.1093/jxb/eri044 (2005).

22. Sato, S., Kamiyama, M., Iwata, N., Furukawa, H. \& Ikeda, H. Moderate increase of mean daily temperature adversely affects fruit set of Lycopersicon esculentum by disrupting specific physiological processes in male reproductive development. Ann Bot. 97, 731-738, DIO: http://dx.doi.org/10.1093/aob/mcl037 (, 2006).

23. Porch, T. G. \& Jahn, M. Effects of high temperature stress on microsporogenesis in heat-sensitive and heat-tolerant genotypes of Phaseolus vulgaris. Plant Cell Environ. 24, 723-731, DIO: http://dx.doi.org/10.1046/j.1365-3040.2001.00716.x (2001). 
24. Peet, M. M., Sato, S. \& Gardner, R. G. Comparing heat stress effects on male-fertile and male-sterile tomatoes. Plant Cell Environ. 21, 225-231, DIO: http://dx.doi.org/10.1046/j.1365-3040.1998.00281.x (1998).

25. Young, L. W., Wilen, R. W. \& Bonham-Smith, P. C. High temperature stress of Brassica napus during flowering reduces micro- and megagametophyte fertility, induces fruit abortion, and disrupts seed production. J Exp bot. 55, 485-495, DIO: http://dx.doi.org/10.1093/jxb/erh038 (2004).

26. Cross, R. H., McKay, McHughen, A. G. \& Bonham-Smith, P. C. Heat-stress effects on reproduction and seed set in Linum usitatissimum L. (flax). Plant Cell Environ. 26, 1013-1020,

DIO: http://dx.doi.org/10.1046/j.1365-3040.2003.01006.x (2003).

27. Johnsen, Ø., Dæhlen, O. G., Østreng, G. \& Skrøppa, T. Day length and temperature during seed production interactively affect adaptive performance of Picea abies progenies. New Phytol. 168, 589596, DIO: http://dx.doi.org/10.1111/j.1469-8137.2005.01538.x (2005).

28. Johnsen, Ø., Fossdal, C. G., Nagy, N., Mølmann, J., Dæhlen, O. G. \& Skrøppa, T. Climatic adaptation in Picea abies progenies is affected by the temperature during zygotic embryogenesis and seed maturation. Plant Cell Environ. 28, 1090-1102, DIO: http://dx.doi.org/10.1111/j.13653040.2005.01356.x (2005).

29. Lacey, E. P. \& Herr, D. Parental effects in plant agolanceolata L. III. Measuring parental temperature effects in the field. Evolution. 54,1207-1217, DIO: http://dx.doi.org/10.1111/j.00143820.2000.tb00555.x (2000).

30. Erickson, A. N. \& Markhart, A. H. Flower developmental stage and organ sensitivity of bell pepper (Capsicum annuum L.) to elevated temperature. Plant Cell Environ. 25,123-130, DIO: http://dx.doi.org/10.1046/j.0016-8025.2001.00807.x (2002).

31. Cao, Y. Y., Duan, H., Yang, L. N., Wang, Z. Q., Zhou, S. C. \& Yang, J. C. Effect of heat stress during meiosis on grain yield of rice cultivars differing in heat tolerance and its physiological mechanism. Acta Agronomica Sinica 34, 2134-2142, DIO: http://dx.doi.org/10.1016/S18752780(09)60022-5 (2008).

32. Iwahori, S. High temperature injuries in tomato. IV. development of normal flower buds and morphological abnormalities of flower buds treated with high temperature. Hort J. 34,33-41, DIO: http://dx.doi.org/10.2503/jjshs.34.33 (1965).

33. Sato, S., Peet, M. M. \& Thomas, J. F. Determining critical pre- and post-anthesis periods and physiological processes in Lycopersicon esculentum Mill. exposed to moderately elevated temperatures. J Exp bot. 53, 1187-1195, DIO: http://dx.doi.org/10.1093/jexbot/53.371.1187 (2002).

34. Fábián, A., Sáfrán, E., Szabó-Eitel, G., Barnabás, B. \& Jäger, K. Stigma functionality and fertility are reduced by heat and drought co-stress in wheat. Front Plant Sci. 10,244, DIO: http://dx.doi.org/10.3389/fpls.2019.00244 (2019).

35. Bokshi, A. I., Tan, D., Thistlethwaite, R. J., Trethowan, R. \& Kunz, K. Impact of elevated CO2 and heat stress on wheat pollen viability and grain production. Funct Plant Biol. 48,503-

514, DIO: http://dx.doi.org/10.1071/FP20187 (2021). 
36. Hedhly, A., Hormaza, J. I. \& Herrero, M. Global warming and sexual plant reproduction. Trends Plant Sci. 14, 30-36, DIO: http://dx.doi.org/10.1016/j.tplants.2008.11.001 (2009).

37. Santiago, J. P. \& Sharkey, T. D. Pollen development at high temperature and role of carbon and nitrogen metabolites. Plant Cell Environ. 42, 2759-2775, DIO: http://dx.doi.org/10.1111/pce.13576 (2019).

38. Bomblies, K., Higgins, J. D. \& Yant, L. Meiosis evolves: Adaptation to external and internal environments. New phytol. 208, 306-323, DIO: http://dx.doi.org/10.1111/nph.13499 (2015).

39. Wang, J. \& Kang, X. Y. Distribution of microtubular cytoskeletons and organelle nucleoids during microsporogenesis in a $2 n$ pollen producer of hybrid Populus. Silvae Genet. 58, 220-226, DIO: http://dx.doi.org/10.1134/S1022795409010189 (2009).

40. Sanders, P. M., Bui, A. Q., Weterings, K., Mclntire, K. N., Hsu, Y. C., Lee, P. Y., Truong, M. T., Beals, T. P. \& Goldberg, R. B. Anther developmental defects in Arabidopsis thaliana male sterile mutants. Sex Plant Reprod. 11, 297-322, DIO: http://dx.doi.org/10.1007/s004970050158 (1999).

41. Cao, H., Li, X., Wang, Z., Ding, M., Sun, Y., Dong, F., Chen, F., Liu, L., Doughty, J., Li, Y.\& Li, Y. X. Histone H2B monoubiquitination mediated by HISTONE MONOUBIQUITINATION1 and HISTONE MONOUBIQUITINATION2 is involved in anther development by regulating tapetum degradationrelated genes in rice. Plant Physiol. 168, 1389-1405, DIO: http://dx.doi.org/10.1104/pp.114.256578 (2015).

42. Yi, J., Moon, S., Lee, Y. S., Zhu, L., Liang, W., Zhang, D., Jung, K. H. \& An, G. Defective Tapetum Cell Death 1 (DTC1) regulates ROS levels by binding to metallothionein during tapetum degeneration. Plant Physiol. 170, 1611-1623, DIO: http://dx.doi.org/10.1104/pp.15.01561 (2016).

43. Worrall, D., Hird, D. L., Hodge, R., Paul, W., Draper, J. \& Scott, R. Premature dissolution of the microsporocyte callose wall causes male sterility in transgenic tobacco. Plant Cell. 4, 759771, DIO: http://dx.doi.org/10.1105/tpc.4.7.759 (1992).

44. Li, B., Chen, X. P., Wu, Y. R., Gu, A. X., Zhang, J. J., Luo, S. X., Gao, X. R., Zhao, J. J., Pan, X. Q. \& Shen, S. X. Gene characterization and molecular pathway analysis of reverse thermosensitive genic male sterility in eggplant (Solanum melongena L.). Hortic Res. 6, 118, DIO: http://dx.doi.org/10.1038/s41438-019-0201-z (2019).

45. Endo, M., Tsuchiya, T., Hamada, K., Kawamura, S., Yano, K., Ohshima, M., Higashitani, A., Watanabe, M. \& Kawagishi-Kobayashi, M. High temperatures cause male sterility in rice plants with transcriptional alterations during pollen development. Plant \& cell physiol. 50, 1911-1922, DIO: http://dx.doi.org/10.1093/pcp/pcp135 (2009).

46. Abiko, M., Akibayashi, K., Sakata, T., Kimura, M., Kihara, M., Itoh, K., Asamizu, E., Sato, S., Takahashi, H. \& Higashitani, A. High-temperature induction of male sterility during barley (Hordeum vulgare L.) anther development is mediated by transcriptional inhibition. Plant Reprod. 18, 91-100, DIO: http://dx.doi.org/10.1007/s00497-005-0004-2 (2005).

47. Oshino, T., Abiko, M., Saito, R., Ichiishi, E., Endo, M., Kawagishi-Kobayashi, M. \& Higashitani, A. Premature progression of anther early developmental programs accompanied by comprehensive 
alterations in transcription during high temperature injury in barley plants. Mol Genet Genomics. 278, 31-42, DIO: http://dx.doi.org/10.1007/s00438-007-0229-x (2007).

48. Papini, A., Mosti, S., Brighigna, L. Programmed-cell-death events during tapetum development of angiosperms. Protoplasma. 207, 213-221, DIO: http://dx.doi.org/10.1007/s00709-018-01336-0 (1999).

49. Varnier, A. L. Mazeyrat-Gourbeyre, F., Sangwan, R. S., Clément, C. Programmed cell death progressively models the development of anther sporophytic tissues from the tapetum and is triggered in pollen grains during maturation. J Struct Biol. 152, 118-128 DIO: http://dx.doi.org/10.1016/j.jsb.2005.07.011 (2005).

50. Shamina, N. V., Gordeeva, E. I., Kovaleva, N. M., Seriukova, E. G. \& Dorogova, N. V. Formation and function of phragmoplast during successive cytokinesis stages in higher plant meiosis. Cell Biol Int. 31, 626-635, DIO: http://dx.doi.org/10.1016/j.cellbi.2006.12.001 (2007).

51. Brown, R. C. \& Lemmon, B. E. Minispindles and cytoplasmic domains in microsporogenesis of Orchids. Protoplasma. 148, 26-32, DIO: http://dx.doi.org/10.1007/BF01403988 (1989).

52. Kang, X. Y. Mechanism of $2 \mathrm{n}$ pollen occurring in Chinese white poplar. J. Beijing For. Univ. 24, 67-70, DIO: http://dx.doi.org/13332/j.1000-1522.2002.zl.014 (2002).

53. De Storme, N. \& Geelen, D. The Arabidopsis mutant jason produces unreduced first division restitution male gametes through a parallel/fused spindle mechanism in meiosis II. Plant Physiol. 155, 1403-1415, DIO: http://dx.doi.org/10.1104/pp.110.170415 (2011).

54. Welburn, J. P., Grishchuk, E. L., Backer, C. B., Wilson-Kubalek, E. M., Yates, J. R. \& Cheeseman, L. M. The human kinetochore Ska1 complex facilitates microtubule depolymerization-coupled motility. Dev Cell. 16, 374-385 DIO: http://dx.doi.org/10.1016/j.devcel.2009.01.011 (2009).

55. Maiato, H., DeLuca, J., Salmon, E. D., Earnshaw, W. C. The dynamic kinetochore-microtubule interface. J Cell Sci. 117, 5461-5477, DIO: http://dx.doi.org/10.1242/jcs.01536 (2004).

56. Wang, J., Li, D.L., Shang, F. N. \& Kang, X. Y. High temperature-induced production of unreduced pollen and its cytological effects in Populus. Sci Rep. 7, 5281, DIO: http://dx.doi.org/10.1038/s41598-01705661-x (2017).

57. Meagher, R. B. The impact of historical contingency on gene phylogeny: Plant actin diversity. Evol Biol. 195-215 (1995).

58. Meagher, R. B., Mc, Kinney, E. C. \& Kandasamy, M. K. Isovariant dynamics expand and buffer the responses of complex systems: the diverse plant actin gene family. Plant Cell. 11, 9951006, DIO: http://dx.doi.org/10.1105/tpc.11.6.995 (1999a).

59. Meagher, R. B., Mc, Kinney, E. C. \& Vitale, A. V. The evolution of new structures: clues from plant cytoskeletal genes. Trends Genet. 157, 278-284, DIO: http://dx.doi.org/10.1016/s01689525(99)01759-x (1999b).

60. Llody, C. W. \& Traas, J. A. The role of F-actin in determining the division plane of carrot suspension cells. Drug studies. Development. 102, 211-221, DIO: http://dx.doi.org/10.1016/0045-6039(88)900292 (1988). 
61. Meagher, R. B. \& Williamson, R. E. The plant cyctoskeleton. In Arabidopsis, E. Meyerowitz and C.Somerville, eds (Cold Spring Harbor, NY: Cold Spring Harbor Laboratory Press). 1049-184 (1994).

62. Hightower, R. C. \& Meagher, R. B. The molecular evolution of actin. Genetics. 114, 315-332, DIO: http://dx.doi.org/10.1016/0735-0651(86)90008-7 (1986).

63. Meagher, R. B. Divergence and differential expression of actin gene families in higher plants. Int Rev Cytol. 125, 139-163, DIO: http://dx.doi.org/10.1016/s0074-7696(08)61218-8 (1991).

64. Higashi-Fujime, S. Active movement in vitro of bundle of microfilaments isolated from Nitella cell. $J$ Cell Biol. 87,569-578, DIO: http://dx.doi.org/10.1083/jcb.87.3.569 (1980).

65. Blatt, M. R., Wessells, N. K. \& Briggs, W. R. Actin and cortical fiber reticulation in the siphonaceous alga Vaucheria sessilis. Planta. 147, 363-375, DIO: http://dx.doi.org/10.1007/BF00379846 (1980).

66. Klein, K., Wagner, G. \& Blatt, M. R. Heavy-meromyosin-decoration of microfilaments from Mougeotia protoplasts. Planta. 150, 354-356, DIO: http://dx.doi.org/10.1007/BF00390169 (1980).

67. Llody, C. W. The cytoskeleton in plant growth and development. Academic Press. 3-29 (1983).

68. Sandquist, J. C., Kita, A. M. \& Bement, W. M. And the dead shall rise: actin and myosin return to the spindle. Dev Cell. 21, 410-419, DIO: http://dx.doi.org/10.1016/j.devcel.2011.07.018 (2011).

69. Mogessie, B. \& Schuh, M. Actin protects mammalian eggs against chromosome segregation errors. Science (New York, N.Y.), 357,6353, DIO: http://dx.doi.org/10.1126/science.aal1647 (2017).

70. De Storme, N., Copenhaver, G. P. \& Geelen, D. Production of diploid male gametes in Arabidopsis by cold-induced destabilization of postmeiotic radial microtubule arrays. Plant physiology, 160, 18081826. DOI: https://doi.org/10.1104/pp.112.208611 (2012).

\section{Tables}

\section{Table 1}

Primer sets used in qPCR-mediated gene expression analysis and the corresponding optimal annealing temperature (AT).

\begin{tabular}{|llll|}
\hline gene & qPCR primer sequence & \multicolumn{2}{c|}{ AT $\left({ }^{\circ} \mathrm{C}\right)$} \\
\cline { 2 - 3 } & forward & reverse & \\
\hline PtActin & GTCCTTCTAACTTCCCAACAGTGC & GACTACCAAAGTGTCTGACCACCA & 55 \\
\hline Pt18s & CCGTCCTAGTCTCAACCATA & CTCTCAGTCTGTCAATCCTTAC & 55 \\
\hline
\end{tabular}

TABLE 2

Aborted pollen production induced by high temperature in Populus canescens 


\begin{tabular}{|c|c|c|c|c|}
\hline $\begin{array}{l}\text { Hours after being } \\
\text { cultured }\end{array}$ & $\begin{array}{l}\text { Dominant meiotic stage } \\
\text { of PMCs }\end{array}$ & $\begin{array}{l}\text { Temperature } \\
\left({ }^{\circ} \mathrm{C}\right)\end{array}$ & $\begin{array}{l}\text { Duration } \\
(\mathrm{hr})\end{array}$ & $\begin{array}{l}\text { Percentage of aborted } \\
\text { pollen (\%) }\end{array}$ \\
\hline \multirow[t]{4}{*}{52} & Leptotene & 38 & 3 & $9.45 \pm 0.92$ \\
\hline & & 38 & 6 & $17.15 \pm 2.56$ \\
\hline & & 41 & 3 & $11.29 \pm 1.77$ \\
\hline & & 41 & 6 & $17.92 \pm 2.55$ \\
\hline \multirow[t]{4}{*}{64} & Zygotene & 38 & 3 & $12.78 \pm 5.06$ \\
\hline & & 38 & 6 & $22.45 \pm 2.21$ \\
\hline & & 41 & 3 & $17.39 \pm 5.65$ \\
\hline & & 41 & 6 & $20.37 \pm 0.83$ \\
\hline \multirow[t]{4}{*}{76} & Pachytene & 38 & 3 & $15.72 \pm 2.02$ \\
\hline & & 38 & 6 & $15.35 \pm 4.33$ \\
\hline & & 41 & 3 & $18.61 \pm 5.20$ \\
\hline & & 41 & 6 & $16.16 \pm 1.35$ \\
\hline \multirow[t]{4}{*}{88} & Diplotene & 38 & 3 & $19.90 \pm 3.03$ \\
\hline & & 38 & 6 & $19.33 \pm 0.96$ \\
\hline & & 41 & 3 & $20.97 \pm 4.10$ \\
\hline & & 41 & 6 & $20.93 \pm 1.70$ \\
\hline \multirow[t]{4}{*}{94} & Diakinesis & 38 & 3 & $14.17 \pm 1.80$ \\
\hline & & 38 & 6 & $13.83 \pm 1.73$ \\
\hline & & 41 & 3 & $16.95 \pm 1.82$ \\
\hline & & 41 & 6 & $20.62 \pm 3.49$ \\
\hline \multirow[t]{5}{*}{100} & Metaphase $\rrbracket$ & 38 & 3 & $10.82 \pm 3.41$ \\
\hline & & 38 & 6 & $13.76 \pm 2.06$ \\
\hline & & 41 & 3 & $25.11 \pm 4.28$ \\
\hline & & 41 & 6 & $24.13 \pm 4.05$ \\
\hline & Control & & & $7.58 \pm 1.32$ \\
\hline
\end{tabular}

\section{TABLE 3}

Formation of lagging chromosomes induced by high temperature exposure in $P$. canescens 


\begin{tabular}{|lllll|}
\hline $\begin{array}{l}\text { Duration } \\
\text { (hr) }\end{array}$ & \multicolumn{2}{l}{$\begin{array}{l}\text { Percentage of PMCs with lagging chromosomes } \\
(\%)\end{array}$} & $\begin{array}{l}\text { Number of lagging } \\
\text { chromosomes }\end{array}$ \\
\cline { 2 - 5 } & Anaphase I & Anaphase II & Anaphase I & Anaphase II \\
\hline 3 & $40.67 \pm 3.06 \mathrm{~b}$ & $33.33 \pm 8.00 \mathrm{~b}$ & $1-13$ & $1-20$ \\
\hline 6 & $55.33 \pm 4.16 \mathrm{~b}$ & $48.67 \pm 3.06 \mathrm{~b}$ & $1-28$ & $1-23$ \\
\hline control & $22.67 \pm 4.16 \mathrm{a}$ & $13.33 \pm 5.03 \mathrm{a}$ & $1-8$ & $1-10$ \\
\hline
\end{tabular}

\section{Figures}



\section{Figure 1}

Aborted pollen and $2 \mathrm{n}$ pollen induced via high temperature exposure and spontaneously aborted pollen in P. canescens (scale bar $=20.0 \mu \mathrm{m}$ ). (a) Aborted pollen (arrow) and high temperature-induced $2 \mathrm{n}$ pollen (arrowhead) in P. canescens. (b) Spontaneously aborted pollen (arrow) in P. canescens. 


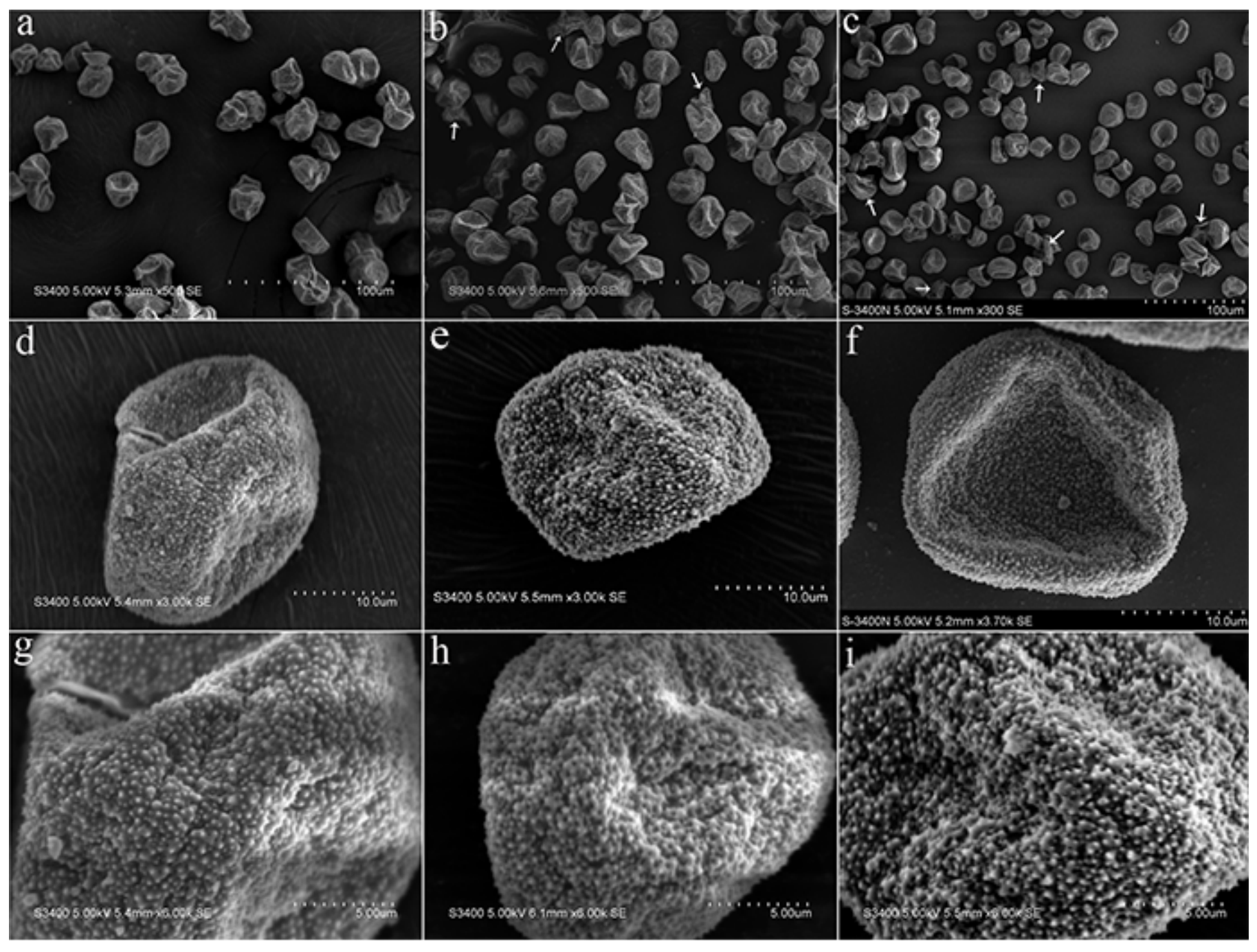

\section{Figure 2}

Scanning electron micrographs of pollen grains of Populus canescens male flower buds exposed to high temperature $\left(38^{\circ} \mathrm{C}\right.$ for 3 or $6 \mathrm{hr}$ ) or $25^{\circ} \mathrm{C}$ (control) at the diplotene stage. (a) Morphology of pollen grains from the control group. (b) Morphology of pollen grains exposed to high temperature $\left(38{ }^{\circ} \mathrm{C}\right.$ for $3 \mathrm{hr}$ ). (c) Morphology of pollen grains exposed to high temperature $\left(38^{\circ} \mathrm{C}\right.$ for $6 \mathrm{hr}$ ). (d) Ectexine deposition of pollen grains from the control group. (e) Ectexine deposition of pollen exposed to high temperature $\left(38^{\circ} \mathrm{C}\right.$ for $3 \mathrm{hr}$ ). (f) Ectexine deposition of pollen exposed to high temperature $\left(38^{\circ} \mathrm{C}\right.$ for $\left.6 \mathrm{hr}\right)$. (g) Details of the ectexine structure in pollen of the control group. (h) Details of the ectexine structure in pollen exposed to high temperature $\left(38^{\circ} \mathrm{C}\right.$ for $3 \mathrm{hr}$ ). (i) Details of the ectexine structure in pollen exposed to high temperature $\left(38{ }^{\circ} \mathrm{C}\right.$ for $\left.6 \mathrm{hr}\right)$. Scale bar $=100(\mathrm{a}-\mathrm{c}), 10(\mathrm{~d}-\mathrm{f})$, and $5 \mu \mathrm{m}(\mathrm{g}-\mathrm{i})$ 

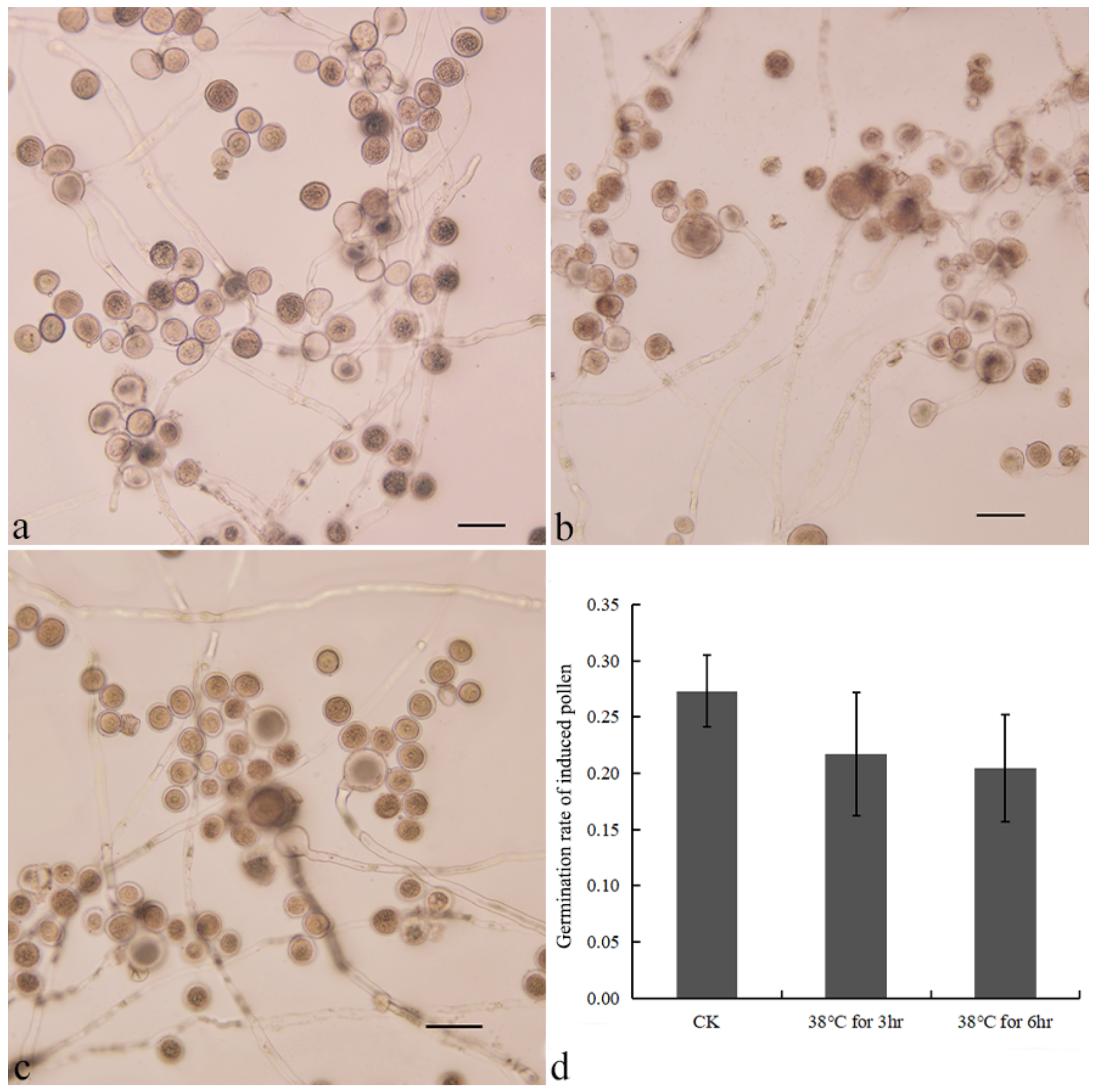

Figure 3

Effect of high temperature on pollen viability in Populus canescens. (a) Germinated fresh pollen grains derived from the control group. (b) Germinated pollen grains derived from the treatment at $38{ }^{\circ} \mathrm{C}$ for $3 \mathrm{hr}$. (c) Germinated pollen grains derived from the treatment at $3838{ }^{\circ} \mathrm{C}$ for $6 \mathrm{hr}$. (d) Pollen viability in flower buds exposed to $38{ }^{\circ} \mathrm{C}$ for 3 or $6 \mathrm{hr}$ in Populus canescens. Control corresponds to $25^{\circ} \mathrm{C}$, that is, standard culture conditions. Bars $=50 \mu \mathrm{m}$. 


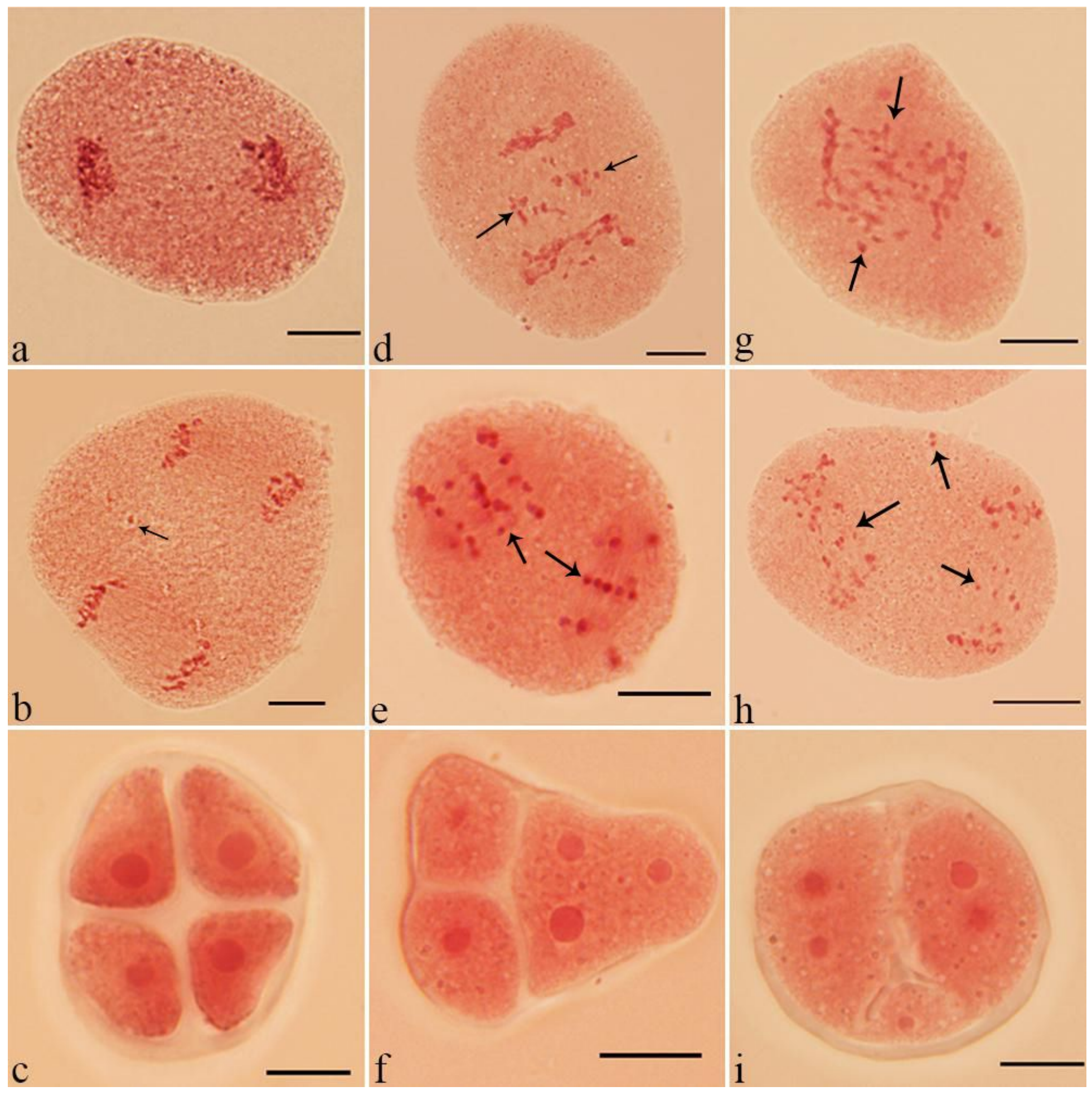

\section{Figure 4}

High temperature-induced lagging chromosomes and aberrant cytokinesis during the microsporogenesis of P. canescens. (a) Anaphase I in a control PMC. (b) Lagging chromosomes (arrow) at anaphase II in a control PMC. (c) Normal tetrad in a control PMC. (d) Lagging chromosomes (arrow) in anaphase I derived from a PMC previously exposed to $38^{\circ} \mathrm{C}$ for $3 \mathrm{hr}$. (e) Lagging chromosomes (arrow) in anaphase II derived from a PMC previously exposed to $38^{\circ} \mathrm{C}$ for $3 \mathrm{hr}$. (f) Polyad derived from a PMC previously exposed to $38^{\circ} \mathrm{C}$ for $3 \mathrm{hr}$. (g) Lagging chromosomes (arrow) in anaphase I derived from a PMC previously 
exposed to $38^{\circ} \mathrm{C}$ for $6 \mathrm{hr}$. (h) Lagging chromosomes (arrow) in anaphase II derived from a PMC previously exposed to $38^{\circ} \mathrm{C}$ for $6 \mathrm{hr}$. (i) Polyad with unbalanced cytokinesis derived from a PMC previously exposed to $38^{\circ} \mathrm{C}$ for $6 \mathrm{hr}$. Bars $=10 \mu \mathrm{m}$.



Figure 5

Tapetum development of anthers of P. canescens male flower buds exposed to high temperature $\left(38^{\circ} \mathrm{C}\right.$ for 3 or $6 \mathrm{hr}$ ) or $25^{\circ} \mathrm{C}$ (control). $(a-e)$ Tapetum development of anthers from the control group. $(\mathrm{f}-\mathrm{j})$ 
Tapetum development of anthers exposed to $38^{\circ} \mathrm{C}$ for $3 \mathrm{hr}$. $(\mathrm{k}-\mathrm{o})$ Tapetum development of anthers exposed to $38^{\circ} \mathrm{C}$ for $6 \mathrm{hr}$. Scale bars $=5 \mu \mathrm{m}$.

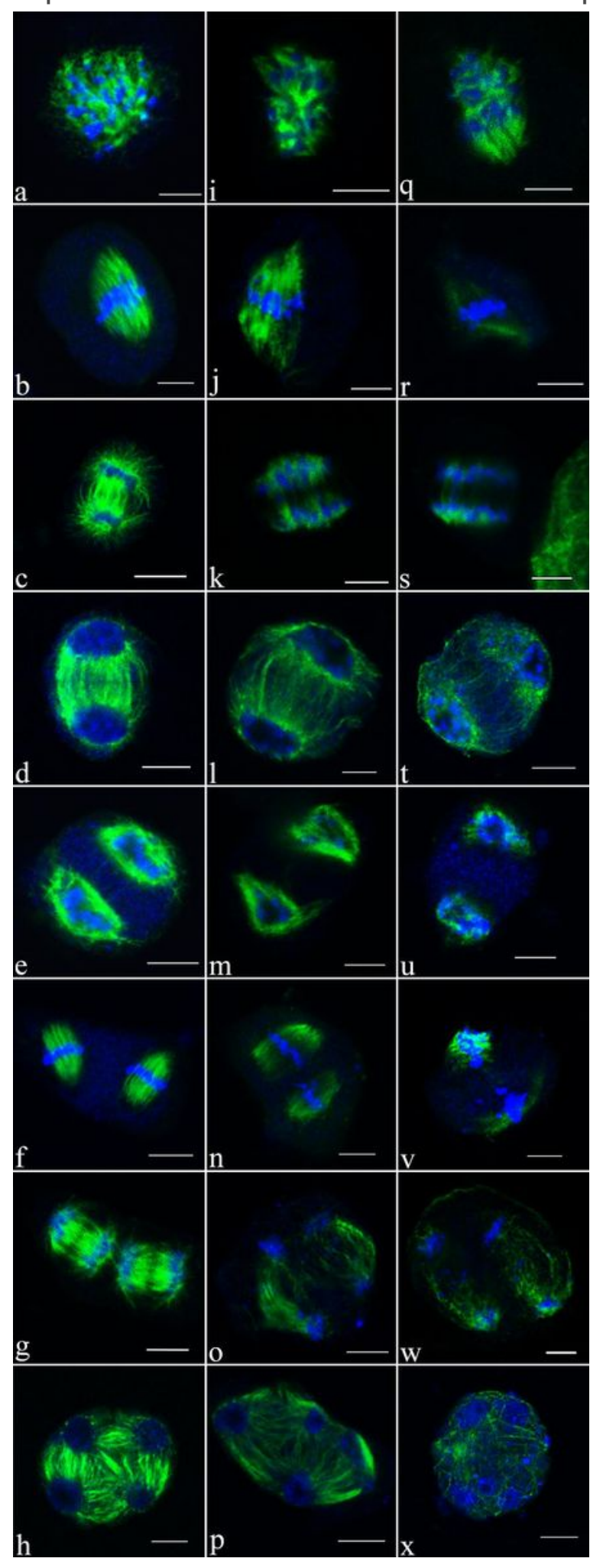

Figure 6

Defects in the meiotic microtubular cytoskeletons of PMCs exposed to $38^{\circ} \mathrm{C}$ for 3 or $6 \mathrm{hr}$ in P. canescens. $(a-h)$ Meiotic microtubule distributions of PMCs from the control group. (i-p) Defects in the meiotic microtubular arrangement of PMCs after treatment at $38^{\circ} \mathrm{C}$ for $3 \mathrm{hr} .(\mathrm{q}-\mathrm{x})$ Defects in the meiotic 
microtubular arrangement of PMCs after treatment at $38^{\circ} \mathrm{C}$ for $6 \mathrm{hr} .(\mathrm{a}, \mathrm{i}, \mathrm{q})$ Diakinesis. $(\mathrm{b}, \mathrm{j}, \mathrm{r})$ Metaphase

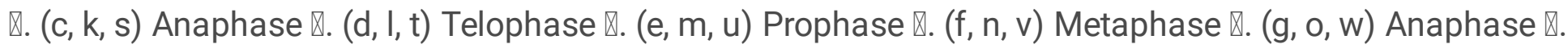

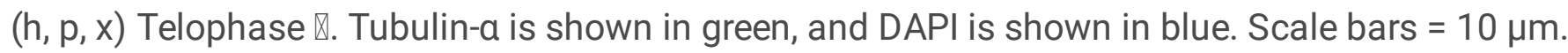

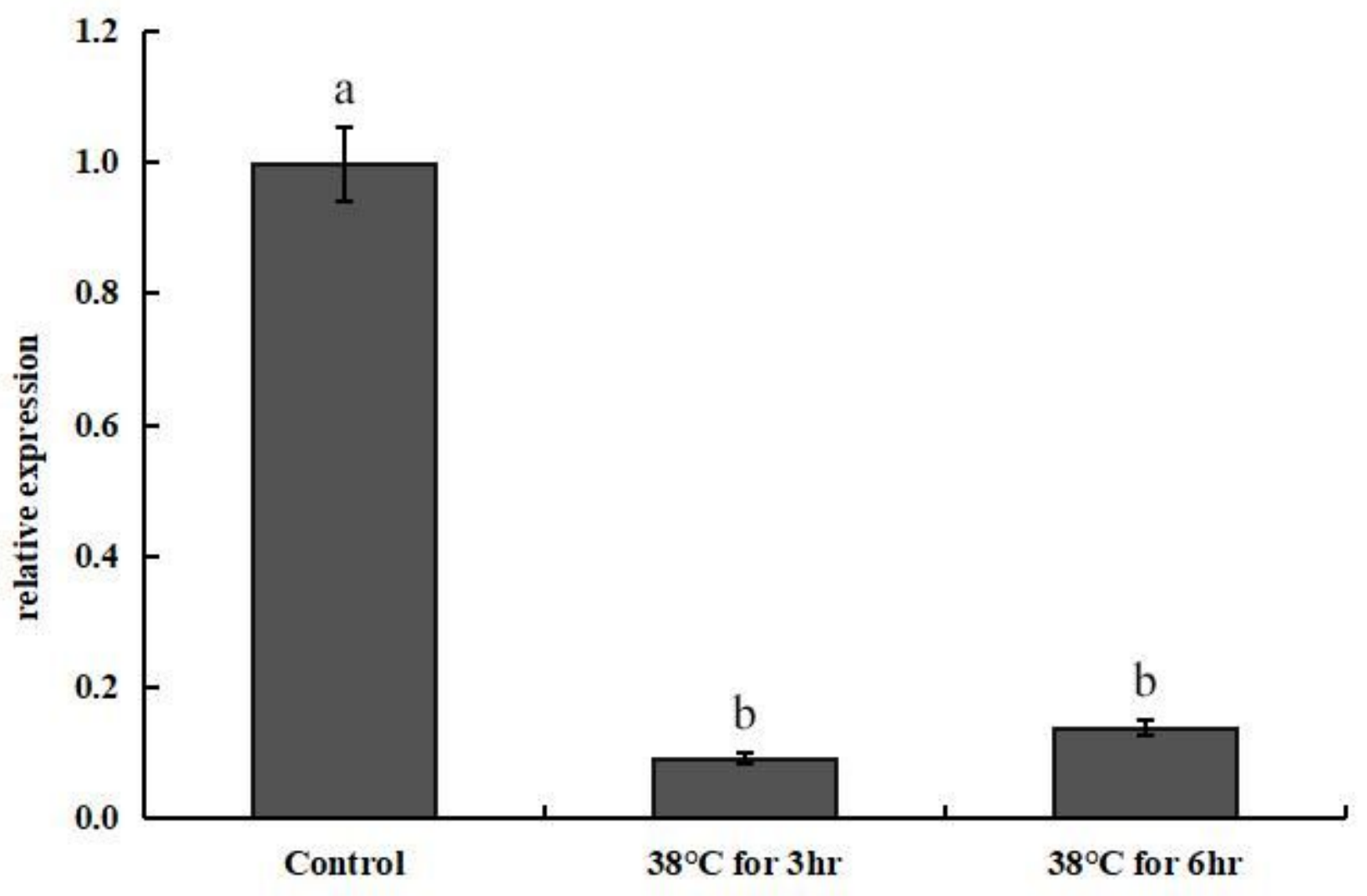

Figure 7

Relative expression of PtActin in meiotic male flower buds of P. canescens exposed to high temperature $\left(38^{\circ} \mathrm{C}\right.$ for 3 or $6 \mathrm{hr}$ ) or $25^{\circ} \mathrm{C}$ (control). 